\title{
Ecology and conservation status of canebrakes in Warangal District of Andhra Pradesh, India
}

\author{
Sateesh Suthari ${ }^{1} \&$ Vatsavaya S. Raju ${ }^{2}$ \\ 1,2 Plant Systematics Laboratory, Department of Botany, Kakatiya University, Warangal, Andhra Pradesh 506009, India \\ Email: ${ }^{1}$ suthari.botany@gmail.com, ${ }^{2}$ rajuvatsavaya@gmail.com (corresponding author)
}

\begin{abstract}
The article describes cane-cum-bat roost site at Palampet (Warangal District, Andhra Pradesh, India). Although notified as a cane reserve by the state government, it is not spared off the usual habitat depletion and destruction. The functional pyramid formed of Calamus-Terminalia-Pteropus is reported here as first of its kind. This article also places on record seven more cane sites besides noting the importance of the ecology of Morancha Vagu and stressing the need for preserving its banks by planting Calamus rotang L. Ecological education to the local people about biodiversity value and conservation at all levels of its organization is called for.
\end{abstract}

Keywords: Bat roosting, canebrakes, conservation, Palampet, Terminalia.
Date of publication (online): 26 December 2012

Date of publication (print): 26 December 2012

ISSN 0974-7907 (online) | 0974-7893 (print)

Editor: Sampath Kumar

\section{Manuscript details:}

Ms \# 03207

Received 18 May 2012

Final received 04 December 2012

Finally accepted 11 December 2012

Citation: Suthari, S. \& V.S. Raju (2012). Ecology and conservation status of canebrakes in Warangal District of Andhra Pradesh, India. Journal of Threatened Taxa 4(15): 3426-3432.

Copyright: (C) Sateesh Suthari \& Vatsavaya S. Raju 2012. Creative Commons Attribution 3.0 Unported License. JoTT allows unrestricted use of this article in any medium for non-profit purposes, reproduction and distribution by providing adequate credit to the authors and the source of publication.

Acknowledgements: Sateesh Suthari is obliged to Dr. V.K. Dadhwal, Project Director, NCP (IGBP), Dr. Sarnam Singh (Deputy Project Director), IIRS, Dehra Dun, for the financial assistance through Vegetation Carbon Pool study. The authors thank the officials of the Andhra Pradesh Forest Department in general and Dr. B. Prabhakar, DFO, Warangal North Forest Division, in particular for his concern to conserve cane site and allowing us to assess its stand structure, Dr. C. Srinivasulu (Osmania University, Hyderabad) for identifying the bat species, and the Head, Department of Botany, Kakatiya University, Warangal, for facilities.

\section{OPEN ACCESS I FREE DOWNLOAD C) (1) Cு}

Canes are one of the principal non-timber forest product (NTFP) species in India. Canes are otherwise called rattans ('rotan' is the local Malaya term for cane). Indonesia dominates rattan export whilst China is a major rattan importer with $59 \%$ of global imports (Hirschberger 2011). Concerned by the reports of depleting rattan resource in the native habitats, World Wildlife Fund (WWF) has been piloting new initiatives focusing on rattan sustainability and traceability since 2009 (Hirschberger 2011). In India, the 'lepidocaryoid' lianas of Arecaceae comprise about 60 species spread among four genera, namely, Calamus L., Daemonorops Blume ex Schult.f., Korthalsia Blume and Plectocomia Mart. \& Blume, and distributed in three major phytogeographical areas-peninsular India, eastern Himalaya and Andaman Nicobar Islands (Renuka 2001). Of these, Calamus (Gr. calamos = reed) is the largest of the palm genera with around 375 species (Sunderland 2012). The canes are spiny palms belonging to the pantropical subfamily Calamoideae of Arecaceae with its members mostly climbing, trailing and acauliscent phanerophytes.

\section{Canebrakes in Andhra Pradesh}

In the "Flora of the Presidency of Madras", Fischer (1932) accounted three species of Calamus from coastal districts of the present-day Andhra Pradesh. They are, as we assess: (i) C. latifolia Roxb. reported from Madgole [Madugula] Hills of Visakhapatnam and Dharwada of West Godavari (Ramarao \& Henry 1996), where it is called 'pemu, peda peka bettam'; (ii) C. rotang $\mathrm{L}$. reported as bettam from the drier tracts of Kurnool, Nellore and Vizianagaram districts. Also recorded from Warangal District along the Morancha channel and below the Ramappa tank (Khan 1953) of Telangana (former Hyderabad State) and Kambakkam Hills of Chittoor District (Chetty et al. 2008) of Rayalaseema; and (iii) C. viminalis 
Willd. reported from Visakhapatnam District and Rampa Hills of East Godavari (Fischer 1932), as well from Isakagadda-Seethampet in Srikakulam District (G.V. Subbarao 62464: collection at MH). Although two cane species are known from Visakhapatnam District, Subbarao \& Kumari (2008) reported only $C$. viminalis var. fasciculatus (Roxb.) Becc. as a rare cane in shade and/or moist localities. It has declined due to coffee plantation and 'podu' (shifting) cultivation (Subbarao \& Kumari 2008). Curiously, it is the only cane species that was reported to be associated with bamboo ('veduru' in Telugu) in Vedurupalli Village in the region (Subbarao \& Kumari 2008). Due to canal construction near Krishnanandi (Kurnool District), the entire dense population of Calamus rotang disappeared in a span of two decades (Ellis 2002) despite being continuously fed by the spring waters of Mahanandi.

Warangal District has a canebrake near Ramappa Temple, Palampet, in a small area. It was mapped and described by Reddy et al. (2008). For its existing biodiversity value, this canebrake was proposed for on-site conservation by Andhra Pradesh State Biodiversity Board. It is the sole, somewhat big patch of cane of about 2ha (which occupied 11.4ha in 1974 and 5.3ha in 2004 - a decline of 53.5\% of the area in three decades and about $28.23 \%$ loss in the last eight years) (pers. obs.), known to survive in the whole of Telangana region. The present article is a sequel to the recent concerted efforts by the local people to burn and convert the cane-habitat-cum-bat-roosting site into paddy fields, notwithstanding the fact that is a notified reserve residing alongside the road, proximate to the Ramappa Temple and Palampet Village.

\section{Results and Discussion}

1. New canebrake sites discovered: During the aboveground vegetational carbon estimation study, the authors discovered a series of canebrakes (Suthari \& Raju 2011) though smaller and patchy along the downstream and away from Ramappa tank in a $5 \mathrm{~km}$ stretch in the northwestern direction. It is locally called 'chapa barige teega'. Besides the main patch $\left(18^{0} 15^{\prime} 42.5^{\prime \prime} \mathrm{N} \& 79^{\circ} 57^{\prime} 02.9^{\prime \prime} \mathrm{E} ; 201 \mathrm{~m}\right)$, the following eight new cane sites are found along Morancha Vagu and reported here for the first time (Table 1).

2. Ecology of canebrake at Palampet: In order to know the health status of the cane (Calamus rotang L.) ecosystem (Palampet Village, Mandal Venkatapur,
Table 1. New cane patches discovered along the downstream of Ramappa and Morancha Vagu.

\begin{tabular}{|c|c|c|c|}
\hline & Latitude & Longitude & Altitude (m) \\
\hline 1 & $18^{0} 15^{\prime} 05.8^{\prime \prime}$ & 79056'28.4" & $205^{*}$ \\
\hline 2 & $18^{\circ} 17^{\prime} 02.0^{\prime \prime}$ & $79^{\circ} 56^{\prime} 59.3^{\prime \prime}$ & 200 \\
\hline 3 & $18^{0} 17^{\prime} 12.9^{\prime \prime}$ & $79^{0} 56^{\prime} 52.9^{\prime \prime}$ & 199 \\
\hline 4 & $18^{0} 17^{\prime} 16.9^{\prime \prime}$ & $79^{\circ} 56^{\prime} 52.6^{\prime \prime}$ & 199 \\
\hline 5 & 18017'19.0"' & 79056'57.7"' & 199 \\
\hline 6 & $18^{0} 17^{\prime} 24.7^{\prime \prime}$ & $79^{0} 57^{\prime} 02.0^{\prime \prime}$ & 198 \\
\hline 7 & $18^{0} 17^{\prime} 33.0^{\prime \prime}$ & 79057'01.5" & 198 \\
\hline 8 & $18^{0} 19^{\prime} 43.8^{\prime \prime}$ & $79^{\circ} 52^{\prime} 41.8^{\prime \prime}$ & $193^{* *}$ \\
\hline
\end{tabular}

* - Near Ramappa tank; ** - Morancha Vagu, near Dharmaraopet

Division Mulugu, Warangal District), the ecology of the habitat was studied. It is to gather baseline data and to find indicator species to facilitate the monitoring of vegetational changes due to the driving abiotic and/or biotic factors.

Abiotic environment: It is a prevailing tropical environment, with additional humidity realized by evapotranspiration from the great water body (Ramappa tank) nearby and transpiration from the wet paddy fields all around. The region receives southwest monsoon between May-August and the annual rainfall is $1100 \mathrm{~mm}$. The annual temperature ranges from $30-43{ }^{\circ} \mathrm{C}$. Morancha Vagu, the natural drain from Ramappa tank with its twists and turns, ensures water flow throughout the year and runs about $35 \mathrm{~km}$ serving as a drain-cum-water provider to about 4,856.23ha of agricultural land before emptying into Maneru, a tributary of the Godavari River. The sandy loam with rich litter contributed by cane and deciduous trees and buttresses of arjuna trees holding the wet soil, collectively created the swamp. The local temperature is $2-3{ }^{\circ} \mathrm{C}$ lesser than the surroundings.

Biotic environment: It is a tropical dry deciduous forest dominated by riparian elements such as Terminalia arjuna (Roxb. ex DC.) Wight \& Arn. and Barringtonia acutangula Gaertn.

(A) Animal communities residing, resting, foraging and passing through the canebrake: The conspicuous elements are the noisy fruit bats, Pteropus giganteus Brünnich, 1782 roosting on tree tops, Apis dorsata Fabricius, 1793 (Giant Honey Bees) housing and abandoning the hives on high branches of Arjuna Tree, butterfly species (largely members of families Pieridae (whites and sulphurs) and Papilionidae (swallow- 
tails) as pollinators, dragonflies, water insects, beetles, besides the grazers like cattle, sheep and goats. About 20 monkeys (Macaca mulatta Zimmermann, 1780: Cercopithecidae) including young ones were found resting. No conflict was noticed between bats and bees, birds or monkeys in our visits.

(B) Plant Community inside and bordering the Canebrake: The species are presented according to the growth habit and habitat: (a) Trees - top storey: (i) Indigenous forest elements: Albizia odoratissima (L.f.) Benth., Cordia dichotoma G. Forst., Ficus virens Aiton, Holarrhena pubescens Wall., Holoptelea integrifolia (Roxb.) Planch., Terminalia arjuna and T. bellirica (Gaertn.) Roxb., (ii) Planted/Naturalized species: Acacia nilotica (L.) Delile, Albizia saman (Jacq.) F. Muell., Millingtonia hortensis L.f., Prosopis cineraria Druce and P. juliflora (Sw.) DC.; (b) Trees - under storey (small trees to shrubs): Alangium salviifolium (L.f.) Wangerin, Barringtonia acutangula (L.) Gaertn. (along the stream), Butea monosperma (Lam.) Taub, Ficus hispida L.f., Grewia tiliifolia Vahl, Pavetta indica L., Steblus asper Lour. and Strychnos nux-vomica L.; (c) Palms/Lianas: Calamus rotang is the predominant ascending palm in the core area besides the few planted and/or running wild Borassus flabellifer $\mathrm{L}$. and Phoenix sylvestris (L.) Roxb. and the liana Derris scandens (Roxb.) Benth. along the margin of the swamp; (d) Climbers/stragglers: Abrus precatorius L., Capparis oblongifolia Forssk., C. zeylanica L., Cardiospermum halicacabum L. var. microcarpum (Kunth) Blume, Coccinea grandis (L.) J. Voigt, Desmodium triflorum (L.) DC., Gymnema sylvestre (Retz.) Schult., Ipomoea sepiaria J. Koenig ex Roxb., Momordica charantia L., Momordica dioica Roxb. ex Willd., Olax scandens Roxb., Operculina turpethum (L.) Silva Manso, Phyllanthus reticulatus Poir., Teramnus labialis (L.f.) Spreng., Tinospora cordifolia (Willd.) Miers, Tragia plukenetii Radcl.-Sm. and Tylophora indica (Burm.f.) Merr.; and (e) Ground cover: Achyranthes aspera L., Abutilon indicum (L.) Sweet, Anisomeles indica (L.) Kuntze, Boerhavia diffusa L., Cynodon dactylon (L.) Pers., Cyperus rotundus L., Grangea maderaspatana (L.) Desf., Heliotropium indicum L., Kyllinga odorata Vahl, Phyllanthus amarus Schumach. \& Thonn., Plumbago zeylanica L. and Urena lobata L.

Vegetation of the stream: (a) Aquatic: (i) Rootedsubmerged: Ottelia alismoides (L.) Pers.; (ii) Rootedemergent: Actinoscirpus grossus (L.f.) Goetgh. \& D.A.
Simpson, Ludwigia octovalvis (Jacq.) P.H. Raven, Nymphaea nouchali Burm.f., Persicaria barbata (L.) H. Hara and P. hydropiper (L.) Delarbre in the middle of the stream and Aeschynomene indica L., Alternanthera sessilis (L.) R. Br. ex DC., Ammannia baccifera L., Echinochloa colona (L.) Link, Eclipta prostrata (L.) L., Hygrophila auriculata (Schumach.) Heine and Ipomoea aquatica Forssk. along the margins, and (b) Amphibious: Centella asiatica (L.) Urb., Cyanotis axillaris (L.) D. Don ex Sweet, Ludwigia perennis L., Melochia corchorifolia L., Phyla nodiflora (L.) Green and Phyllanthus debilis Klein ex Willd.

Alien invasives: Along the margin of the canebrake are Ageratum conyzoides L., Chromolaena odorata (L.) R.M. King \& H. Rob., Lantana $\times$ aculeata L., Senna auriculata (L.) Roxb., S. obtusifolia (L.) H.S. Irwin \& Barneby, S. occidentalis (L.) Roxb., S. sophera (L.) Roxb., Waltheria indica L. and Xanthium strumarium L. among the herbs and Millingtonia hortensis (found only one tree, planted along the roadside and spreading with root suckers), Zizyphus mauritiana L. and saplings of Azadirachta indica A. Juss. (future threat) amongst the running wild trees. Ipomoea fistulosa Mart. ex Choisy, the problematic amphibious plant species, occupied the mid stream at one place (Image 1g).

\section{Biodiversity}

The diversity of the canebrake, like any habitat can be looked at genetic, species and ecosystem levels.

(a) Genetic level: Sreekumar \& Renuka (2006) demonstrated the extent of genetic diversity at intraand inter-population levels in Calamus thwaitesii Becc., using molecular markers. Interestingly, the genetic polymorphism was discovered to be more within the population $(70.79 \%)$ than the inter populations (29.21\%). Such information is sought for C. rotang, for its populations across habitats in India.

(b) Species level: The habitat is largely occupied by the population of a single species, Calamus rotang. It is a dioecious, trailing or ascending palm, with perennation by rhizome (Image $1 \mathrm{j}$ ). Both pistillate and staminate plants were found with regular flowering and fruiting (Image 1b). For a sexually breeding dioecious species, sex ratios are important. In this primary report, the sex ratio and species diversity indices for the site could not be carried out since the habitat is a dense thicket and burnt in part. However, there are 
reports about the breeding system of this species being affected due to presence of either of the two morphs in a particular habitat. For example, among the planted canes at Lalbagh (Karnataka), the populations were staminate in $C$. rotang or pistillate in C. delessertianus Becc. (Manohara et al. 2007).

(c) Ecosystem level: No significant differences in growth form, leaf size, cane diameter and phenology were noticed along the gradient, that is, altitude of the Morancha Vagu, down the stretch of $5 \mathrm{~km}$. The size of cane (4-6x6-8 m on canopy; $3 \times 6 \mathrm{~m}$ on bank) was based on the stream bund maintained abutting the fields and the trees available for ascending. The consistent riparian element found was Barringtonia acutangula and at places, the invasive Ficus hispida providing the opportunity. The liana competitors are Derris scandens and Combretum album Pers. The leaves of Calamus are good in intercepting the splat effect of rain and thereby improving the water-holding capacity of the soil while its litter enriches the soil (Image 1c). The fruits are edible.

If one looks at the cane singularly of the ecosystem, it is largely the alpha (population) diversity. It is due to the accompanied differences between the two morphs of this dioecious species. The beta diversity (inter-population variation that is with other patches of cane around) is limited. It is because of the presence of individuals (clones) of either of the two forms (staminate or pistillate) occurring in small patches along the Morancha vagu.

Bat-cane axis: Bats are reported as a dispersal agent at least for Calamus thwaitesii whose pulpy fruits are sweet and edible (Renuka 1995; Sreekumar $\&$ Renuka 2006). Primates like macaques and human beings are fond of its fruits. This provides a functional link among bat-roosting, cane-farming and monkeys at places in India.

Cane site as roost site: The canebrake with its associated co-dominant emergent tall-stature trees, especially the species Terminalia arjuna and $T$. bellirica (Combretaceae) harbours the Indian Flying Fox Pteropus giganteus Brünnich, 1782 native to India, Sri Lanka, Pakistan, Nepal, Bhutan, Bangladesh, Myanmar and China.

The genus Pteropus Brission, 1762 is represented by four species in South Asia. Pteropus giganteus, distributed throughout India, is a keystone species listed by IUCN as 'Least Concerned', for its wide distribution and colony-size. It is strongly colonial and roosts on high trees in large aggregations. It is primarily nocturnal, known for its ecological role as pollinator and seed disperser of native tree species thereby playing a positive role in tropical forest succession and biodiversity nesting. In India, Pteropus giganteus has a role in the pollination of very important, economic and ethnic plant Madhuca longifolia (J. Koenig ex L.) J.F. Macbr. (syn. M. latifolia; Nathan et al. 2009) which abounds locally aside the cultural value assigned - either considered sacred (Marimuthu 1988) or evil. It is phytophagous (feeding on fruits, petals and leaves) and is one of the 13 species of fruit bats found in India. Despite the constructive role these bats play, all bat species except Salim Ali's Fruit Bat (Latidens salimalii Thonglongya, 1972) are categorized as vermin (which can be captured or killed) under Schedule V of the Indian Wildlife (Protection) Act, 1972 and amended acts. This needs to be reversed (Singaravelan et al. 2009). It is also the demand of the present authors since the ecological services rendered, such as the dispersal of pollen and fruit, outweigh the damage done to the ripe fruits of orchards. So, Pteropus giganteus is not to be regarded as a pest and instead efforts should be made to ensure its conservation (Mahamood-Ul-Hassan et al. 2010).

Pteropus giganteus (vernacular 'gabbilam'; Image $1 \mathrm{~g}$ inset) prefers the tall, robust, emergent (top canopy) trees, either heavily foliated, proximate to water bodies or near habitations, plantations and agricultural fields for roosting whilst feeding on fruits of wild and/ or cultivated plants like areca nut, banana, cashew, figs, guava, jackfruit, jamaican cherry, litchi, mango, papaya, plantain, sapota and tropical almond. Since more of these fruits are of cultivated trees, there is a conflict between bat conservation and fruit growers. Besides, Indian Flying Fox is increasingly not only deprived of natural choice of food but also its roosting sites. The threats are due to highway development and consequent felling of large/huge/aged-trees, rising of plantations of neotropical species and/or Australian species which bear no edible fruits, selective cutting of berry/drupe-bearing native trees in the forests for harvesting the fruits, fodder and NTFPs, application of pesticides, and capturing bats for the alleged medicinal values. The prime roost (arjuna) tree (Image $1 \mathrm{~h}$ ) is a well-known cardio-tonic plant besides bearing scores of other medicinal uses, serving as the food plant 

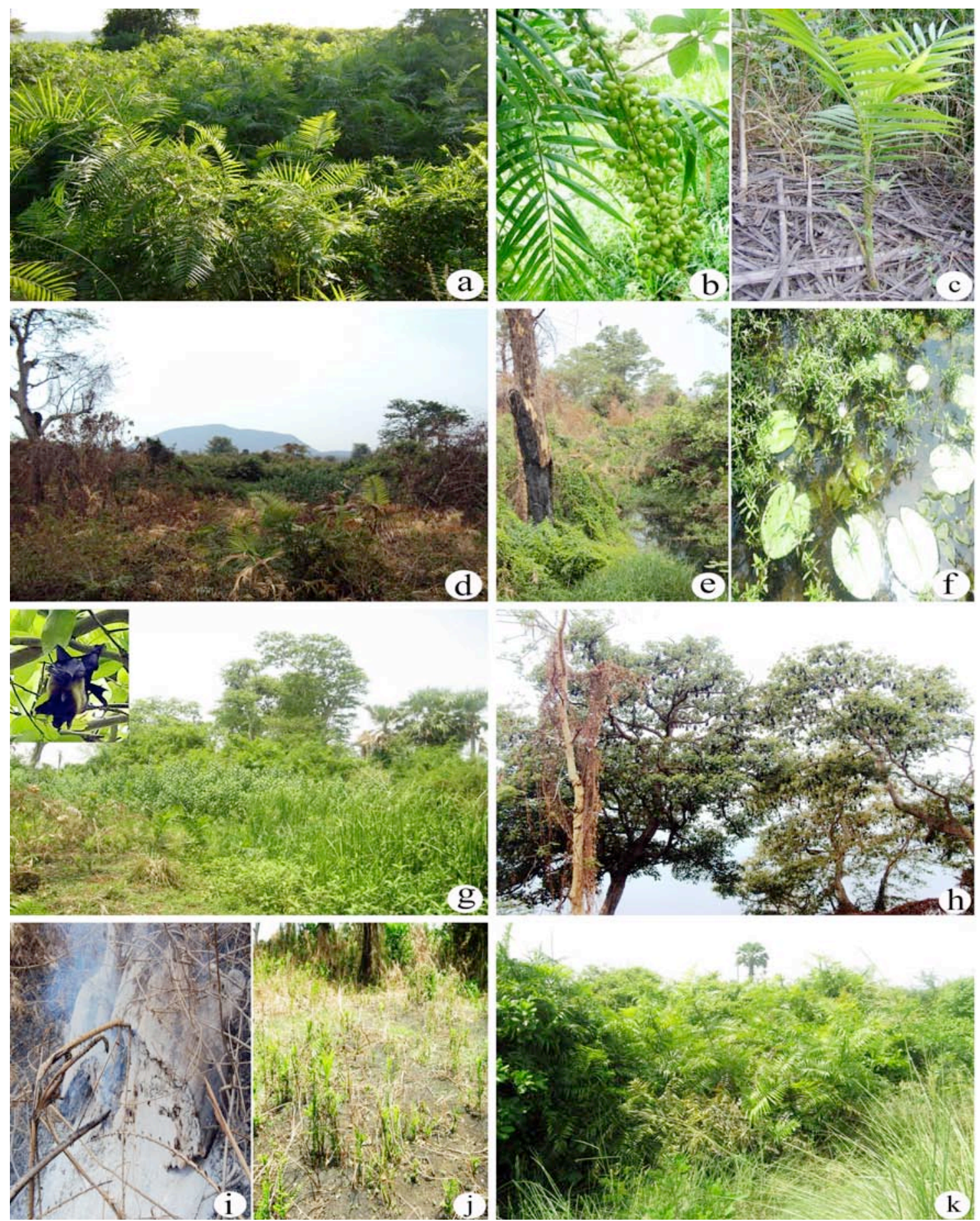

Image 1. Canebrake cum bat (Indian Flying Fox) roost site.

a - View of cane swamp in 2008; b - Fruits (unripe) of cane; c - Emerging cane shoot (ramet) and rich litter accrued; d - View of the canebrake after the recent man-made fire (January, 2012); e\&f - Natural vegetation of the stream; $\mathrm{g}$ - Part of the bat roost in the southwest margin of the swamp (inset Pteropus ginganteus), note the invasive alien Ipomoea fistulosa choking the stream; $\mathrm{h}$ - Main roost on two trees (Terminalia bellirica and $T$. arjuna from left to right) in the core area; $\mathrm{i}$ - Dead cane and still burning cut base of Arjuna Tree; j - Regenerating cane and naked ground predisposed for invasives; $k$ - The cane site discovered near Ghanpur (Mulugu).

for tassar silk worm and its ecophysiological role (e.g. water-holding capacity, keeping the banks of streams intact; natural dispersal by its floating fruits with water movement and regeneration from stocks). Although coincidence, the wings are common to the roosting bat (Pteropus) and the fruits of preferred 
host the arjuna tree (Pentaptera arjuna as named by Roxburgh), providing buoyancy in media like air and waters, respectively. The other roost tree, Terminalia bellirica, is also an important medicinal plant species, being one of the 'triphalas' from which the Ayurvedic laxative 'triphala churn' is prepared.

In wet evergreen forests of Western Ghats, tall huge trees of species of Calophyllum L., Dipterocarpus C.F. Gaertn., Garcinia L. and Pterocarpus Jacq. whereas the exotic and planted Australian trees like Casuarina equisetifolia L. along the coast and species of Eucalyptus L'Hér. elsewhere constituted the roosting trees for Pteropus giganteus. The liana associates of roost trees are species of Derris Lour., Entada Adans. and Smilax L. For the first time, Calamus rotang is added to this list. The ground of roost site is planted with thickets (by bat seeding) of Lantana $\times$ aculeata as buffer to deter the cattle and people so that the bats are undisturbed (Chakaravarty et al. 2008). In the present site, it is served by the cane, Streblus asper, Alangium salviifolium and the network of climbers mentioned above. In Karnataka, a bat roost site on one acre land was spared by a private individual for conservation as heritage site (Chakravarthy et al. 2008). It is something exemplary.

The bat species showed considerable fidelity with the present roost site and the corresponding author of this article has been observing the colony over the past 25 years. The huge tall primary forest tree species are Terminalia arjuna (erra/tella/veru maddi) and Terminalia bellirica (tandra/tani). The former provided the required opportunity to the bat with its architecture (very high remote branching and radiant canopies), smooth shining bark which offers additional visibility during night. As we note, it offers a clear view to the bat and receives the cool breeze vertically from below and horizontally passing breeze from nearby Ramappa tank and wet paddy fields around, the required freefall take-off, and the coriaceous green foliage put forth every year convenes the desired shade, shelter and protection from the ultraviolet rays. The bats preferred only Terminalia species despite the presence of more or less equally tall and strong trees available around, monkey menace and Apis dorsata forming the hives. The bats were found changing among these trees and between the two sub-colonies along the stream, separated by $500 \mathrm{~m}$. Perhaps, this is the first record of Terminalia trees as bat roost.
Threats to the conservation of cane-cum-bat roost site: The canes are known for their ethnic and economic uses besides the ecological role. Therefore, they are to be conserved forth right against the imminent threats like: (i) the occurrence of the cane in small or restricted (patchy) fragile ecosystems, (ii) habitat destruction, 'podu' cultivation and spread of fire-promoting invasive plant species with their litter, and (iii) monkey menace, grazing by cattle and fuelwood collection.

Political ecology: This subject has an approach to increase our understanding of the relationship between resource control and governance though it has not yet deeply engaged with ethnic studies. The destiny of conservation of the present habitat at Palampet is mainly driven by the prevailing local politico-economic environment. The landless people, policy of the government towards 'podu' and 'patta', and the general psyche of the public towards forest lands predispose the cane site for land use conversion. Our personal enquiry revealed that the local people desire the land to be acquired for farming despite the consequences. It is because the cane-site is fertile land - an island amidst the sea of paddy fields. The people believe that the land is wasted by forest department to maintain an unworthy plant species (as the locals do not use it). They are encouraged by the fact that they could manage a portion of land adjoining the canebrake for a village common (i.e. burial ground). The local politicians and revenue officials concerned have their interplay, though it is not their domain. Therefore, it is impossible to conserve the surviving canebrake unless and until the villagers of Palampet are educated and convinced that this cane site is no less important than the nearby treasures such as the Ramappa temple or Ramappa Lake, both built by the Kakatiyas (c.1213). The swamp is to be surveyed and fenced and notified to the public through repeated announcements that it is a serious offence to cut or remove the cane or disturb the bats. One must see that the local school/college management adopts the site for biodiversity conservation and ecological studies by the students, and they are made party to the environmental education to the citizens of the villages around. 


\section{REFERENCES}

Chakravarthy, A.K., H.M. Yeshwanth, L.V. Kumar \& N.R.P. Kumar (2008). Giant Indian Fruit Bat Pteropus giganteus Brünnich roost in Karnataka, South India: a case for preservation as a heritage site. Bat Net CCINSA Newsletter 9(1): 13-15.

Chetty, K.M., K. Sivaji \& K.T. Rao (2008). Flowering Plants of Chittoor District, Andhra Pradesh, India. Students Offset Printers, Tirupati, 490pp.

Ellis, J.L. (2002). Plant diversity niches in the Nallamalais of the Eastern Ghats, pp. 1-4. In: Proceeding of the National Seminar Conservation of Eastern Ghats. March 24-26, 2002. Environment Protection Training and Research Institute, Hyderabad.

Fischer, C.E.C. (1932). Flora of the Presidency of Madras. [Calamus: 1562-1568]. Vol. III. Adlard \& Son, Limited, W.C. London, 1347-2017pp.

Hirschberger, P. (2011). Global Rattan Trade: Pressure on Forest Resources, Analysis and Challenges. Ed. E. Duncan. WWF, Vienna, Austria, 81 pp. [http://awsassets.panda.org/ downloads/global_rattan_trade_report.pdf]. Downloaded on 08 May 2012.

Khan, M.S. (1953). Forest Flora of Hyderabad State. Government Press, Hyderabad-Dn, 364pp+i-xix.

Mahamood-Ul-Hassan, M., T.L. Gulraiz, S.A. Rana \& A. Javid (2010). The diet of Indian Flying-Foxes (Pteropus giganteus) in urban habitats of Pakistan. Acta Chiropterologica 12(2): 341-347.

Manohara, T.N., S.N. Ramaswamy \& G.R. Shivamurthy (2007). Calamus - dwindling resources? Current Science 92(3): 290-292.

Marimuthu, G. (1988). The sacred Flying Fox of India. Bats 6(2):10-11.

Nathan, P.T., T. Karuppudurai, H. Raghuram \& G. Marimuthu (2009). Bat foraging strategies and pollination of Madhuca latifolia (Sapotaceae) in southern India. Acta Chiropterologica 11(2): 435-441.
Ramarao, N. \& A.N. Henry (1996). The Ethnobotany of Eastern Ghats in Andhra Pradesh, India. Botanical Survey of India, Calcutta, 259 pp.

Reddy, C.S., C. Pattanaik, E.N. Murthy \& V.S. Raju (2008). Mapping and monitoring of Calamus rotang L. in adjoining areas of Ramappa Lake, Andhra Pradesh using remote sensing and GIS. Current Science 94(5): 575-577.

Renuka, C. (1995). Reproductive biology of rattans. Report of an Expert Consultation held at Los Banos, Phillipines, 8-11 May 1995, pp. 135-139. In: Williams, J.T., I.V.R. Rao \& A.N. Rao (eds.). Genetic Enhancement of Bamboo and Rattan. Appendix 12. Scenario Publications (India), Noida.

Renuka, C. (2001). Palms of India: status, threats and conservation strategies, pp. 197-209. In: Umashanker, R., K.N. Ganeshaiah \& K.S. Bawa (eds.). Forest Genetic Resources: Status, Threats and Conservation Strategies. Oxford \& IBH Publishing Co. Pvt. Ltd., Calcutta.

Singaravelan, N., G. Marimuthu \& P.A. Racey (2009). Do fruit bats deserve to be listed as vermin in the Indian Wildlife (Protection) \& amended acts? A critical review. Oryx 43(4): 608-613.

Sreekumar, V.B. \& C. Renuka (2006). Assessment of genetic diversity in Calamus thwaitesii Becc. (Arecaceae) using RAPD markers. Biochemical Systematics and Ecology 34: $397-405$.

Subbarao, G.V. \& G.R. Kumari (2008). Flora of Visakhapatnam District (Andhra Pradesh)-Vol. 2. Botanical Survey of India, Kolkata, 536pp.

Sunderland, T.C.H. (2012). A taxonomic revision of the rattans of Africa (Arecaceae: Calamoideae). Phytotaxa 51: 1-76. [http:/www.mapress.com/phytotaxa/content/ 2012/f/ pt00051p076.pdf]. Downloaded on 01 October 2012.

Suthari, S. \& V.S. Raju (2011). Further discovery of canebrakes in Warangal District, Andhra Pradesh, p.34. National Conference on Plants and People, March 29-30, 2011. Kakatiya University, Warangal. 